University for Business and Technology in Kosovo

UBT Knowledge Center

Oct 27th, 9:00 AM - 10:30 AM

\title{
Development of Policies for Acquiring Municipal Land, through Planning Mechanisms to Achieve the Defined Goals in Prishtina
}

\section{Burbuqe Hydaverdi}

Directorate of Strategic Planning and Sustainable Development, burbuqe.hydaverdi@rks-gov.net

Follow this and additional works at: https://knowledgecenter.ubt-uni.net/conference

Part of the Architecture Commons

\section{Recommended Citation}

Hydaverdi, Burbuqe, "Development of Policies for Acquiring Municipal Land, through Planning Mechanisms to Achieve the Defined Goals in Prishtina" (2018). UBT International Conference. 6. https://knowledgecenter.ubt-uni.net/conference/2018/all-events/6

This Event is brought to you for free and open access by the Publication and Journals at UBT Knowledge Center. It has been accepted for inclusion in UBT International Conference by an authorized administrator of UBT Knowledge Center. For more information, please contact knowledge.center@ubt-uni.net. 


\title{
Development of Policies for Acquiring Municipal Land, through Planning Mechanisms to Achieve the Defined Goals in Prishtina
}

\author{
Burbuqe Hydaverdi ${ }^{1}$ \\ Municipality of Prishtina - Directorate of Strategic Planning and Sustainable \\ Development, st. UÇK, No.2, 10000 Prishtina, Kosovo \\ burbuqe.hydaverdi@rks-gov.net
}

\begin{abstract}
Prishtina and other capitals in the region are daily facing enormous requests to access public utilities. The development of construction trend that is still ongoing, with a combined architecture between the traditional and the modern, on one hand is contributing and generating revues to the budget of the capital city, and on the other hand is creating difficulties in providing infrastructural, social and public services.

Spatial planning documents not always reflect the reality, because urban development is taking place rapidly in spite of legal capabilities to amend the development plans.

The areas for public and social infrastructure have been defined by the Urban Regulatory Plans, mostly on private lands, lacking the Municipal land. Their expropriation is providing to be very challenging and in many cases unachievable.

The low budget for expropriation and the necessity to gain municipal land pushed the Municipality of Prishtina to implement these goals planned by the Plans through forms of agreement for transfer of construction rights. Such expropriation method remains to be further analyzed and reconsolidated as a mechanism for acquiring and gaining municipal land.

The aim is to facilitate the legal framework for finding the best ways of developing and satisfying the public and social interest, through appropriate and acceptable planning methods for expropriations of private land in order to provide for the citizens of Prishtina a healthy social, economic and environmental life.
\end{abstract}

Keywords: Expropriation, Public and Social Infrastructure, Urban Planning, Land Management.

\section{Introduction}

The City of Prishtina is located in the north-eastern part of Kosovo and cover an area of 7768.8 ha, with a central position in the Balkans Peninsula. (Prishtina M. A., 2013, p. 27) Prishtina is also the biggest economic, administrative, educational and cultural center in Kosova (Prishtina M. A., 2013, p. 10).

Following the war of 1999, the development of the city by illegal construction affected the urban structure of the city and the major part of this structure underwent transformation.

Through the years, different forms of construction and destruction have been formative and transformative of Prishtina, and this history is part of what goes into the post-conflict city of today (Norman, 2014).

Over the past 17 years since the war in Kosovo ended, many successful businesses have been developed as the result of illegal takeovers of publicly-owned buildings and agricultural land (Prebreza, 2016). 
Today, more than $1 / 4$ of the whole Kosova population lives in Prishtina, majority of which are deprived of minimal utilities (Planning, 2010, p. 23).

By the growth of population, the demands for access to public infrastructure are also increasing. The Municipality of Prishtina "suffers" from the lack of municipal land under its ownership and it is one of the challenges it encounters daily as a result of not implementing the plans. The majority of these public and social infrastructure (school, kindergarten, basic health care institution, public park, roads etc.) are planned on private plots. Several ways of expropriation have been determined from the central and local government. In the capital of Kosovo, taking into consideration the low annual budget for implementation of public goals, apart from financial compensation, there were also undertaken several steps towards facilitation of gaining public land. This process results to be very slow and sometimes disputable, despite excessive demands and needs.

The plan should be effectuated largely through public capital investment on publicly owned. Support by the citizenry would be essential to provide the political will for making the necessary investment (M.Levy, 2017, p. 42).

The aim of this research paper is to present the current situation faced by the Municipality of Prishtina and to find new mechanisms for compensation of land and examination of the existing ones on acquirement of municipal land in order to implement municipal services for a healthy, social, economic and environmental life.

\section{Lack of municipal lands impact on the loss of international investment}

Forms of tenure and property rights to land vary from one society to another, since they reflect other areas of social and civic life. In all cases, rights normally include checks and balances. Modern states require land policies to govern access, tenure, use and development. These take the form of land laws, rules and procedures as well as of specialist bodies for land administration (UN-HABITAT, 2008).

Good city governance and management is a prerequisite for competitiveness and livability in any city (Stren, 2001). Architecture and urban planning are always political affair (Vockler, 2008, p. 16). Planning and politics are intimately related, and people who rise in planning generally have political smarts (M.Levy, 2017, p. 7). The main challenge to public planning is the way in which politics and planning thinks about the outcomes of the process, and a major challenge is the onesided focus on consensus as goal (Jonathan Metzger, 2015, p. 115).

As of 1986, by the Law on Expropriation 46/86, the general interest was determined by the detailed urban regulatory plan, thus there were detailed regulatory plans. The Strategic Urban Development Plan for Prishtina, 2004 - 2020, and the Law on Spatial Planning No 2003/14, described regulatory urban plans, in which public services were determined, but, unfortunately, no strategy was defined on how to compensate for such private properties. All of these were based on the Law on Expropriation of Immovable Property 03/L-139, which determines that these properties shall be expropriated only by monetary compensation.

The war of 1999 opened a new chapter of history to the citizens of Kosovo. Known that during the period 1998-1999, Kosovo was in a chaotic situation with regard to developments in the field of construction and stabilization of the whole territory, where the order and the luck of institutions was almost at the ground zero. Such a need to build and stabilize the country was a challenge in itself to just the European Community addressed the latter to take the main burden in construction, development and stabilization of Kosovo in the future (Bajraktari, 2011, p. 5).

Until year 2008 and based on the constitutional framework, UNMIK was the authority with a reserved competency for expropriation. With a new constitution coming into force, a set of laws have been adopted which regulate the area of public interest and enable the implementation of 
plans (law on expropriation, law on construction land, law on cadaster, and recently the law on public-private partnership) (NALAS, 2009, p. 52).

Even though the Constitution of the Republic of Kosovo states that "the right to own property is guaranteed", and that "no one shall be arbitrarily deprived of property", the practice by urban plans is proving the contrary. By delaying the implementation of spatial and urban plans, the municipalities often prevent individuals from using their real estate for an indefinite time. Thus, the municipalities frequently fail to provide affected property right holders with legal redress against their actions (OSCE, 2006).

On the other hand, Land Law is a about the connections between people and land. It is also the relationships between people, jostling for space and allocating resources. It is as fascinating as people themselves, and as dynamic (Cooke, 2012, p. 1).

Even nowadays, after so many years, the Republic of Kosovo still does not have a Law for Construction Land, and in private property and existing legislation often represent serious obstacles to the organization of space when facilitates of public interest need to be built on such property. Since quality legislation is lacking in this field, it is often difficult to reconcile public interest and protection rights for a property subject to expropriation (Vockler, 2008, p. 26).

Municipality in Kosovo do own land and thus implementation of social infrastructure in usually done on municipal land (NALAS, 2009, p. 52), but according to urban and detailed regulatory plans in force, due to the fact that the Municipality possesses a small number of municipal lands, the majority of public areas have been planned in private lands. In these cases, expropriation does not begin at all, or it lasts for decades.

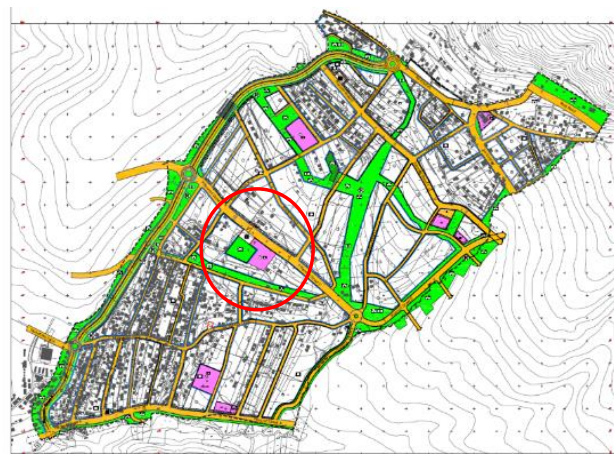

Figure 1. Planning of public and social infrastructure by URP "Mati1"

(Source:https://kk.rks-gov.net/prishtine/prishtina4/planet-rregullative/)

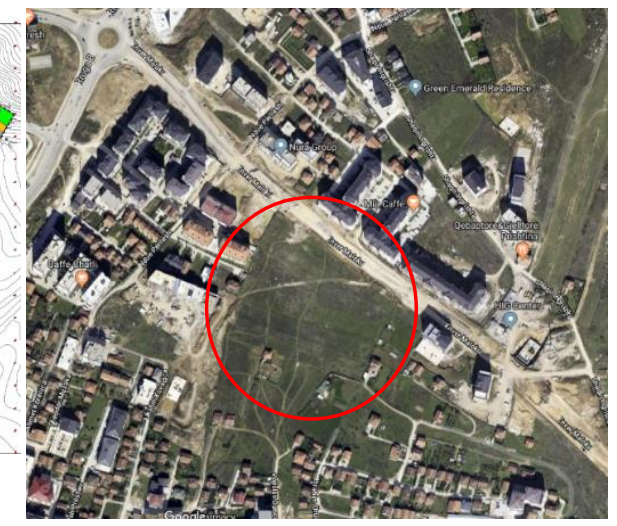

Figure 2. Planning of public and social infrastructure in private properties (Source: https://www.google.com/maps/)

According to the Urban Regulatory Plan of "Mati1" from 2005, this area was planned for public and social infrastructure (school, basic health care institution and public park), even nowadays those plots are empty because municipality did not achieve an agreement with private owner and those are not expropriated.

On the other hand, despite the needs for such areas, the capital city does not have sufficient budget to expropriate them. The only relief for the land owner is to "pray" that such planning contents do not go through his/her land. Such situation forced the citizens to be interested in protecting and justifying only their land, without considering that in the future their children will not have any space for social, cultural and educational development. Based on municipal budget for year 2018 , there were only 500 thousand euro for expropriation. 
Different countries have regulated this phenomenon based on legislation in different ways. For example, the Planning law allows local authorities to expropriate up to 40 per cent of a plot for public purpose without paying compensation, provided the purpose of the expropriation is one of the following: the construction or widening of the roads and recreation grounds or the building of the educational, cultural, religious, health and sport facilities (Holzman-Gazit, 2016).

The capital city of the Republic of Kosovo, lacking the municipal property or having usurped property, risks the benefit to receive international donations for investment in educational and social areas, sometimes it even does not receive investment. Therefore, the opportunity to attract donations appears to be difficult and challenging. As specific example, the European Bank for Reconstruction and Development (EBRD) has agreed to start negotiations for providing 60 million euro (\$73.9 million) financing for a road upgrade project in Kosovo's capital Pristina (Zhitija, 2018), but this process cannot take place without expropriating all of lands that are affected by the trace of this ring and the cost of expropriation appears to be around three times more than the cost of construction.

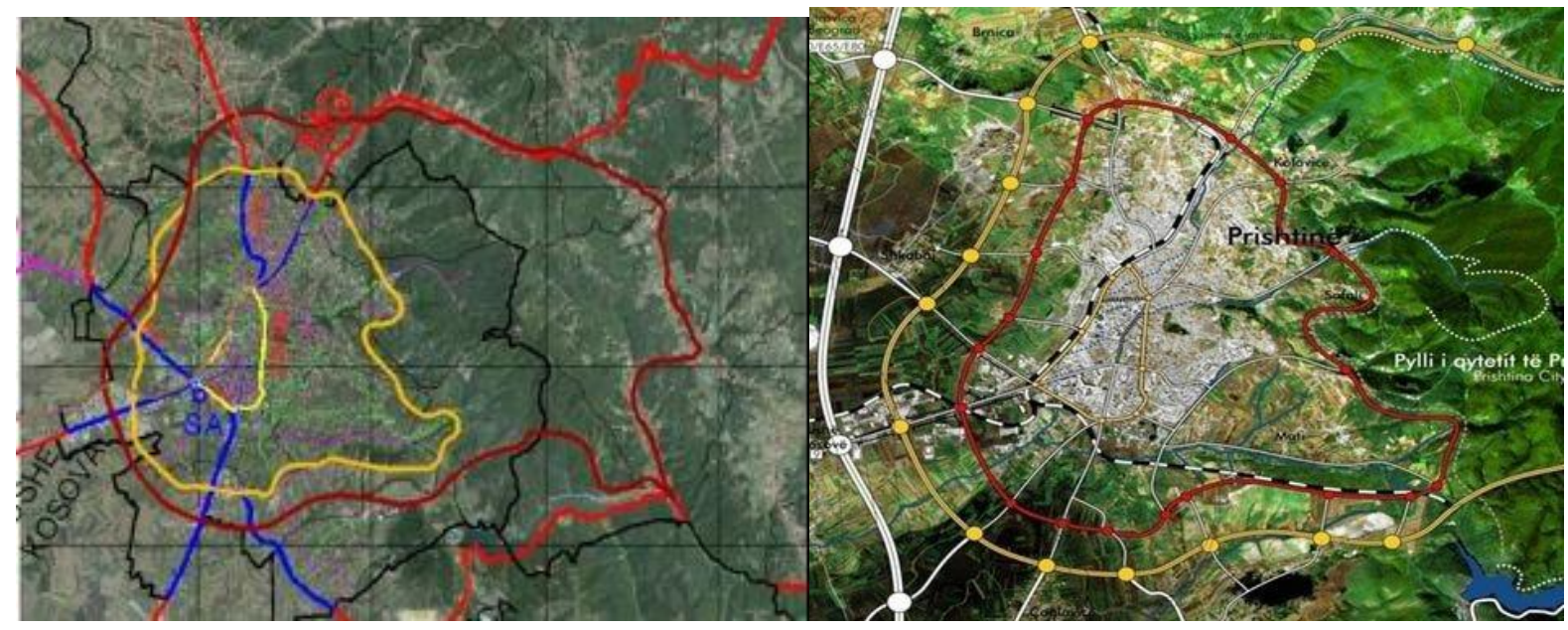

Figure 1. Inner Ring Road (Source: UDP, p.104)

Figure 2. Inner Ring Road (Source: https://archive. $k$ oha.net/?id=8\&l=5865)

The Urban Development Plan of Prishtina 2012-2022 neither provides any strategy (proposal) for compensation, or expropriation, and on the other hand it has foreseen the expansion of urban area and growth of population in the city. Expansion of urban area, illegal construction and growth of population in the capital city are having effect on high demands for provision of public services.

But, stopping urban growth is not an option. The world's rural population has essentially reached its peak; but the global urban population is projected to double by 2030 . Urbanization will require increasing supplies of land, more efficient land use and accessible forms of tenure; this is particularly the case in major cities, but also for growing small and medium-sized towns and in peri-urban areas (UN-HABITAT, 2008). Higher levels of commitment to infrastructure may be a need given that service level deficiencies will likely become a bottleneck for Kosovo's aspirations to join the EU and reduce urban and rural poverty (Group, 2017).

While, infrastructure development will be an important part of Kosovo's economic development for yours to come. There are growing demands for quality housing, office space, government buildings, schools, roads, highways and basic sanitation system, among other infrastructures needs (Publications, 2013, p. 121), the capital will face with major challenges and should be founded alternatives to achieve the planned goals. 


\section{Conclusions and Recommendations}

Central level, especially Ministry of Environment and Spatial Planning and all Municipalities of Kosovo including Capital, must try to find better and more convenient alternatives for implementation of planned goals, through development planning policies for gaining public space determined by the development plans. Those authorities has to work more on doing regulations to establish and implement transfer development rights, zoning bonuses or compensation in exchange for providing a public benefit. The methods for their expropriation should have adequate approach and mechanism in order to accomplish their implementation within a convenient and necessary timeframe. Those methods and mechanism for public benefit has to be clearly determined in the laws, administrative instructions and planning documents. By finding new methods in planning process as smart models for expropriation of public contents will affect the saving of municipal budget in economic, social and environmental aspect.

Municipality of Prishtina, has to analyze if the practices for gaining municipal land in regional capitals be adaptable in Prishtina case. These models of expropriation will be a mechanism for achieving development goals in order to provide a healthy, social, economic and environmental life to the citizens of Prishtina.

\section{References}

1. Bajraktari, H. (2011). Kosovo's Past Strategies and Future Challenges of European. Norderstedt: University of Prizren.

2. Cooke, E. (2012). Land Low. (Second, Ed.) Oxford: OXFORD University Press.

3. Group, T. W. (2017, January). Republic of Kosovo Systematic Country Diagnostic. Retrieved from The World Bank: http://documents.worldbank.org/curated/en/282091494340650708/pdf/Kosovo-SCDFINAL-May-5-C-05052017.pdf

4. Holzman-Gazit, Y. (2016). Land Expropriation in Israel - Law, Culture and Society. New York: Routledge.

5. Jonathan Metzger, P. A. (2015). Planning Against the Political. New Your: Routledge.

6. M.Levy, J. (2017). Contemporary Urban Planning. (Eleventh, Ed.) New York and London: Routledge Taylor \& Francis Group.

7. NALAS, N. o. (2009). The Legislation and Analysisof the Implementation of Spatial and Urban Planning in Albania, Kosovo, Macedonia, Moldova, Republic Serbska and Turkey as Compares to the Case of Denmark. Ljubljana: SOS: Association of Municipalities and Towns of Slovenia \& NALS: Network of Associations of Local Authorities of South East Europe.

8. Norman, R. (2014, February 12). Shifting experiences of places in Prishtina. Retrieved May 18, 2018, from Eurozine: https://www.eurozine.com/shifting-experiences-of-placesin-prishtina/

9. OSCE. (2006, December 13). Expropriations in Kosovo. Retrieved from OSCEOrganization for Security and Co-operation in Europe: https://www.osce.org/sq/kosovo/23287?download=trues

10. Planning, M. o. (2010). Spatial Plan of Kosova - Spatial Development Strategy 20102022+. Prishtina: Institute for Spatial Planning. 
11. Prebreza, V. (2016, November 30). Kosovo Struggles with Long-Term Illegal Building Boom. Retrieved June 26, 2018, from Prishtina Insight: https://prishtinainsight.com/kosovo-struggles-long-term-illegal-building-boom/

12. Prishtina, M. A. (2013). Municipal Development Plan of Prishtina 2012-2022. Prishtina: Department of Urbanism, Construction and Environmental Protection.

13. Prishtina, M. A. (2013). Urban Development Plan "Pishtina 2012-2022". Prishtina: Department of Urbanism, Construction and Envirnonmental Protection.

14. Publications, I. B. (2013). KOSOVO - Doing Business for Everyone Guide. Washington, DC: International Business Publications.

15. Stren, M. F. (2001). The Challenge of Urban Government - Policies and Practices. Washington, D.C.: The Wold Bank Institute.

16. UN-HABITAT, G. L. (2008). Secure Land Rights for All. Retrieved June 11, 2018, from Indiana University:

https://dlc.dlib.indiana.edu/dlc/bitstream/handle/10535/6047/secure\%20land\%20rights.pdf ?sequence $=1 \&$ is Allowed $=\mathrm{y}$

17. Vockler, K. (2008). Prishtina is Everywhere - Turbo Urbanism : the Aftermath of a Crisis. Amsterdam: Archis.

18. Zhitija, V. (2018). ERDB Agrees to Consider Financing for Road Upgrade in Kosovo's Prishtina Mayor. Retrieved June 13, 2018, from SeeNews: https://seenews.com/news/ebrdagrees-to-consider-financing-for-road-upgrade-in-kosovos-pristina-mayor-603230 